\title{
Variation in antral follicle development during the follicular phase of the oestrous cycle in red deer (Cervus elaphus) hinds
}

\author{
B. J. McLeod ${ }^{1}$, L. M. Meikle' ${ }^{1}$, M. W. Fisher ${ }^{1}$, T. R. Manley ${ }^{1}$, \\ D. A. Heath ${ }^{2}$ and K. P. McNatty ${ }^{2}$ \\ ${ }^{1}$ AgResearch, Invermay Agricultural Centre, Private Bag 50034, Mosgiel, New Zealand; \\ and ${ }^{2}$ AgResearch, Wallaceville Animal Research Centre, PO Box 40063, Upper Hutt,
} New Zealand

The aim of this study was to quantify antral follicle populations in cyclic red deer hinds and to monitor follicle development leading to ovulation. Oestrus was synchronized with exogenous progesterone and ovaries were recovered approximately $0,12,24$ or $36 \mathrm{~h}$ (follicular phase) or 10 days (luteal phase) after progesterone withdrawal ( $n=5$ per group). All follicles $\geqslant 2 \mathrm{~mm}$ in diameter were dissected out, health status was assessed, follicular fluid oestradiol content was measured, granulosa cells were harvested and their capacity for oestradiol and cAMP production was determined. The time of oestrus and the preovulatory LH surge were monitored in five control hinds. Deer ovaries contained $26.6 \pm 3.45$ (mean \pm SEM) follicles $\geqslant 2 \mathrm{~mm}$ in diameter (range 4-81), with at least one large antral follicle (diameter: $8.3 \pm 0.38 \mathrm{~mm}$ ) per

\section{Introduction}

Strategies used to control breeding in deer have been adapted largely from treatments used with some success in other domestic livestock. However, in red deer (Cervus elaphus) hinds the effectiveness of such treatments given to synchronize oestrus, achieve superovulation or induce ovulation during the non-breeding season has been variable (Asher et al., 1994; Fennessey et al., 1994). Although little information is currently available regarding follicle development in cervine species, the success or failure of these techniques, which are based on the administration of exogenous gonadotrophic hormones, has often been attributed to the presence or absence of healthy follicles on the ovaries at the time of treatment. It has been suggested that inter-animal variation in response to treatment may reflect wide differences in the number or health status of the antral follicles present in individual hinds. There are two other characteristics of reproduction in red deer hinds that may or may not reflect the status of follicle populations in individual hinds. Firstly, the occurrence of twins or of multiple ovulations is relatively rare in this species (Fisher et

Email: bernie.mcleodb@agresearch.co.nz hind. There was a strong correlation between follicle size and granulosa cell population $\left(r^{2}=0.676\right)$. Approximately half $(50.7 \%)$ of the follicles were classified as healthy, with the percentage classified as atretic decreasing with increasing follicle size. Neither the total number of antral follicles nor their size distribution differed significantly among groups. There were significantly more $(P<0.05)$ healthy follicles at $24 \mathrm{~h}$ after progesterone withdrawal than at $0 \mathrm{~h}$, when large oestrogenic follicles had fewer granulosa cells, lower follicular fluid oestradiol concentrations and lower aromatase activity $(P<0.05)$ than did those from other groups. In summary, antral follicle development in red deer is similar to that in other monovulatory ruminants, and at least one large follicle is present at all stages of the oestrous cycle. al., 1989), suggesting that few large antral follicles enter the final stages of preovulatory development. Secondly, there is a high degree of synchrony in the time of onset of breeding activity among animals in a wild population (Lincoln and Guinness, 1973). This finding could indicate that in all hinds antral follicles are present that are capable of responding to an appropriate ovulatory stimulus.

In other monovulatory ruminants (for example cows and some sheep breeds), there are waves of follicle development over the oestrous cycle, with several antral follicles entering a growth phase concurrently. A number of growing, apparently healthy antral follicles emerge simultaneously early in the follicular phase of the cycle, but only one of these follicles undergoes the exponential preovulatory growth phase that culminates in ovulation. The development of this single, large oestrogenic follicle (the dominant follicle) suppresses the growth, and results in widespread atresia, of its cohort follicles (McNatty et al., 1982, 1984a; McNatty and Henderson, 1987). At the time of luteolysis, the follicle destined to ovulate may lie within the pool of healthy follicles > $2 \mathrm{~mm}$ in diameter (McNatty, 1982; Webb et al., 1989; Fortune, 1994) and this follicle may emerge as an active oestrogenic follicle within $10 \mathrm{~h}$ of luteolysis (McNatty et al., 1982). In all species studied, it has been shown that these later stages of follicle development (for 
example, follicles $\geqslant 3 \mathrm{~mm}$ in diameter in sheep and pigs) are under the control of the gonadotrophic hormones FSH and LH (McNatty et al., 1982, 1990; Hunter et al., 1992).

The effectiveness of controlled breeding strategies will depend not only on the number and stage of development of the antral follicles present, but also on their physiological condition. The health status of individual follicles can be assessed on the basis of their morphology (Hay et al., 1976) or on their ability to secrete oestradiol in response to exposure to gonadotrophins in vitro (McNatty et al., 1984a). Furthermore, at least in some species (for example, sheep: Henderson et al., 1985; pigs: Hunter et al., 1992), it is known that specific plasma membrane receptors for both $\mathrm{LH}$ and FSH are located in granulosa cells, and that the initial action that follows receptor-hormone binding for these hormones is the stimulation of adenosine cyclic $3^{\prime} 5^{\prime}-$ monophosphate (cAMP) production. Therefore, cAMP production by granulosa cells in vitro provides a valuable indicator of the status of the follicle from which the cells were recovered. In particular, cAMP production demonstrates the responsiveness of that follicle to stimulation by $\mathrm{LH}$ or FSH.

The present study was undertaken to determine antral follicle populations and follicle health status in red deer hinds during the breeding season and to determine the patterns of follicle development over the follicular phase of the oestrous cycle. The time of 'luteolysis' and, thus, the onset of the follicular phase of the oestrous cycle, was synchronized artificially by the administration and subsequent withdrawal of exogenous progesterone. Preliminary reports of some of these data (follicle populations) have been presented elsewhere (McLeod et al., 1994, 1996).

\section{Materials and Methods}

\section{Animals}

Follicle development was assessed in ovaries collected from adult red deer hinds $(n=25$; mean live weight $95.6 \pm 2.1 \mathrm{~kg}$ ) during the breeding season (April). The time of onset of oestrus and the occurrence of a preovulatory LH surge were monitored in a further five control hinds (mean live weight $96.2 \pm 2.6 \mathrm{~kg}$ ). All 30 hinds were maintained on pasture as a single group at Invermay Agricultural Centre, Mosgiel, New Zealand (latitude $45^{\circ} 53^{\prime} \mathrm{S}$ ). The animals from which ovaries were recovered were fasted overnight before they were either ovariectomized or killed.

All experimental procedures performed had been given prior approval by the AgResearch Invermay Animal Ethics Committee, according to the Animals Protection (Codes of Ethical Conduct) Regulations, 1987.

\section{Treatment and blood sampling}

Oestrus was synchronized in all animals by exposure to a 12 day period of progesterone treatment, administered via intra-vaginal progesterone-releasing devices (EAZI-BREED CIDR, $0.3 \mathrm{~g}$ progesterone; InterAg, Hamilton). A single
CIDR left in situ for 8 days was replaced with a fresh device that was left in situ for the following 4 days to maintain increased plasma progesterone concentrations. Ovaries were recovered either surgically by ovariectomy $(n=12)$ or when the deer was killed ( $n=13)$, before $(t=0$, group 1$)$ or approximately 12 (group 2), 24 (group 3 ) or 36 (group 4) h, or 10 days (group 5) after CIDR withdrawal ( $n=5$ per group).

Blood samples were collected from control hinds (via indwelling jugular vein catheters) at $2 \mathrm{~h}$ intervals from $4 \mathrm{~h}$ before to $72 \mathrm{~h}$ after CIDR withdrawal to enable the time of ovary collection to be related to the time of onset of oestrus and time of the preovulatory LH surge. The time of onset of oestrus was also monitored in these animals by observations of behaviour made at $2 \mathrm{~h}$ intervals from the time of CIDR withdrawal. The behaviour patterns associated with oestrus included: (i) nuzzling the observer; (ii) tail flicking; (iii) standing immobile to pressure applied to the back; and (iv) adopting a hunched, squatting posture. Hinds were deemed to be in standing oestrus if they remained immobile to the back pressure test.

\section{Ovarian tissue collection and preparation}

After recovery, the excised ovaries were placed immediately on ice in Dulbecco's phosphate-buffered saline solution (KC Biological Inc., Lenaxa, KS) and transferred to an adjacent laboratory where they were weighed and all follicles $\geqslant 2.0 \mathrm{~mm}$ in diameter were dissected out under a stereomicroscope. After being dissected free of extraneous tissue, the diameter of each follicle was recorded (to the nearest $0.1 \mathrm{~mm}$ ), the vascularity of the thecal tissue was assessed and the integrity of the oocyte (healthy, degenerating or not found) was noted. Follicular fluid was aspirated from each follicle through a finely drawn Pasteur pipette via a small slit made in the follicle wall, and its volume was measured. Granulosa cells were scraped free of thecal tissue using a fine-wire loop and suspended in Dulbecco's phosphatebuffered saline solution containing 0.1\% (w/v) BSA (Sigma Chemical Company, St Louis, MO) and $20 \mathrm{mmol}$ Hepes buffer $\mathrm{I}^{-1}$ (Sigma; medium A, $\mathrm{pH} 7.4,4.0^{\circ} \mathrm{C}$ ). The granulosa cells were washed, counted by haemocytometer and centrifuged at $900 \boldsymbol{g}$ for $15 \mathrm{~min}$. The supernatant containing the contents of dead cells and contaminants of follicular fluid was discarded and the remaining granulosa cells were recounted.

\section{Granulosa cell aromatase activity}

Granulosa cells collected from each follicle were resuspended in ice-cold medium $A$, containing $0.2 \mathrm{mmol}$ 3-isobutyl-1-methylxanthine $\mathrm{I}^{-1}$ (MIX; Sigma) (medium B, $\left.\mathrm{pH} 7.4,4.0^{\circ} \mathrm{C}\right)$, so that the final cell concentration was $2-4 \times 10^{5}$ cells $\mathrm{ml}^{-1}$. Aliquots $(0.5 \mathrm{ml})$ of these cell suspensions were placed in $10 \mathrm{~mm} \times 75 \mathrm{~mm}$ plastic centrifuge tubes. A further $0.5 \mathrm{ml}$ medium $\mathrm{B}$ alone (time zero incubations) or $0.5 \mathrm{ml}$ medium B containing $2.0 \mu \mathrm{g}$ 
testosterone $\mathrm{ml}^{-1}$ (testosterone incubations) was added and a stopper was placed in the tubes. Depending on the total number of granulosa cells recovered from each follicle, both time zero and testosterone incubations were prepared in duplicate or triplicate. Time zero incubations were then snap frozen at $-70^{\circ} \mathrm{C}$. Testosterone incubations were placed in a shaking waterbath at $37^{\circ} \mathrm{C}$ for $3 \mathrm{~h}$, after which they were snap frozen at $-70^{\circ} \mathrm{C}$. All tubes were then stored at $-20^{\circ} \mathrm{C}$ until the media were assayed for oestradiol content. Aromatase activity of granulosa cells from individual follicles, expressed as ng oestradiol $\left(10^{6} \text { cells }\right)^{-1} \mathrm{~h}^{-1}$, was calculated from oestradiol content of media from testosterone incubations minus those from time zero incubations.

\section{Granulosa cell cAMP production}

Washed granulosa cells were resuspended in ice-cold medium B to final concentrations of $2-4 \times 10^{5}$ cells ml-1. Aliquots $(0.5 \mathrm{ml})$ of these cell suspensions were placed in $10 \mathrm{~mm} \times 75 \mathrm{~mm}$ plastic centrifuge tubes. A further $0.5 \mathrm{ml}$ medium B (time zero incubations) or $0.5 \mathrm{ml}$ medium B containing $200 \mathrm{ng} \mathrm{LH} \mathrm{ml}^{-1}$ (NIH-LH-S17) ( $\mathrm{LH}$ incubations) was added and the tubes were closed with screw caps. Incubations were prepared either in duplicate or triplicate, depending on the total number of granulosa cells recovered.

The $\mathrm{LH}$ incubations were placed in a shaking waterbath at $37^{\circ} \mathrm{C}$ for $45 \mathrm{~min}$, after which the reaction was stopped by further incubation in a waterbath at $80^{\circ} \mathrm{C}$ for $15 \mathrm{~min}$. Time zero incubations were incubated at $80^{\circ} \mathrm{C}$ for $15 \mathrm{~min}$ immediately after addition of the cell suspension. All tubes were stored at $-20^{\circ} \mathrm{C}$ until the incubation media were assayed for CAMP. Production rates of CAMP (mmol $\left(10^{6}\right.$ cells $)^{-1} \mathrm{~h}^{-1}$ ) for granulosa cells from individual follicles were determined from the media content of the $\mathrm{LH}$ incubations minus CAMP content from their equivalent time zero incubations.

\section{Follicle classification}

Follicles were classified as healthy or atretic based on criteria used to describe sheep follicles (McNatty et al., 1985). The following factors were considered when the intact, cleanly dissected follicles were observed at $\times 10$ magnification. Firstly, the presence or absence of blood capillaries within the thecal tissue and the presence or absence of debris in the follicular fluid were noted. In addition, the oocyte was classified as healthy, degenerating or as not found. Oocytes were deemed to be degenerating if they were free of a cumulus cell matrix or if they showed signs of cytolysis, necrosis or loss of spherical shape. Finally, the total number of granulosa cells within each follicle was determined.

Follicle health was classified as one of four categories. Grade 1 follicles had a vascularized theca interna, follicular fluid that was free of debris, a healthy-looking oocyte and a granulosa cell population that was $>$ the $25 \%$ quartile for a follicle of that diameter. Grade 2a follicles also had a vascularized theca interna, but had debris in the follicular fluid, either a healthy or degenerate oocyte and a granulosa cell population that was $<$ the $75 \%$ quartile for a follicle of that diameter. Grade 2b follicles differed from Grade 2a in that they had an avascular theca interna and their follicular fluid was free of debris. Grade 3 follicles had both an avascular theca interna and debris in the follicular fluid and the number of granulosa cells was $<$ the $50 \%$ quartile for a follicle of that diameter. Follicles in this class could have either a healthy or degenerate oocyte.

Only Grade 1 follicles are regarded as healthy, and those classed as Grades 2a, 2b and 3 represent follicles in progressive stages of degeneration and atresia. Non-atretic follicles were classified arbitrarily as 'oestrogenic' if they had: (i) a granulosa cell population that was > the fiftieth percentile for a follicle of that diameter; (ii) a follicular fluid oestradiol concentration of $>50 \mathrm{ng} \mathrm{ml}^{-1}$; and (iii) measurable aromatase activity or CAMP production in vitro. Within each animal, the 'dominant' non-atretic follicle was deemed to be the oestrogenic follicle that had the highest follicular fluid oestradiol concentration, highest aromatase activity (oestradiol production) and greatest cAMP production.

\section{Hormone assays}

Plasma LH concentrations were determined using the heterologous double-antibody RIA method described for deer plasma by Meikle and Fisher (1996). All samples were completed within a single assay in which the intra-assay coefficient of variation was $11.7 \%$. The limit of detection was $0.08 \mathrm{ng} \mathrm{LH} \mathrm{m}^{-1}$ plasma.

Concentrations of oestradiol in follicular fluid and in granulosa cell incubation media were measured using the tritiated oestradiol method described for sheep by McNatty et al. (1981). Results were expressed as ng oestradiol per $10^{6}$ cells. Follicular fluid oestradiol concentration was measured directly without extraction, in diluted (10-100 times dilution with $0.1 \mathrm{~mol}$ phosphate buffered saline $\mathrm{I}^{-1}$ ) aliquots of follicular fluid. The limit of detection was $1.0 \mathrm{ng}$ $\mathrm{ml}^{-1}$.

cAMP production by granulosa cells was determined using the method described by McNatty et al. (1985), and cAMP production was expressed as pmol per $10^{6}$ cells. The inter- and intra-assay coefficients of variation were both $<10 \%$ and the limit of detection was 0.02 pmol per $10^{6}$ cells.

\section{Analysis of data}

Initially, data from follicles dissected from all animals in this study, irrespective of the time of ovary collection, were collated to characterize deer follicles on the basis of size, health status, number of granulosa cells and capacity for hormone secretion. To our knowledge, this has not been undertaken previously in this species, although there is extensive information for other farmed species (sheep: McNatty et al., 1982; pigs: Hunter et al., 1992; cattle: McNatty et al., 1984a). All except two of the follicles that 


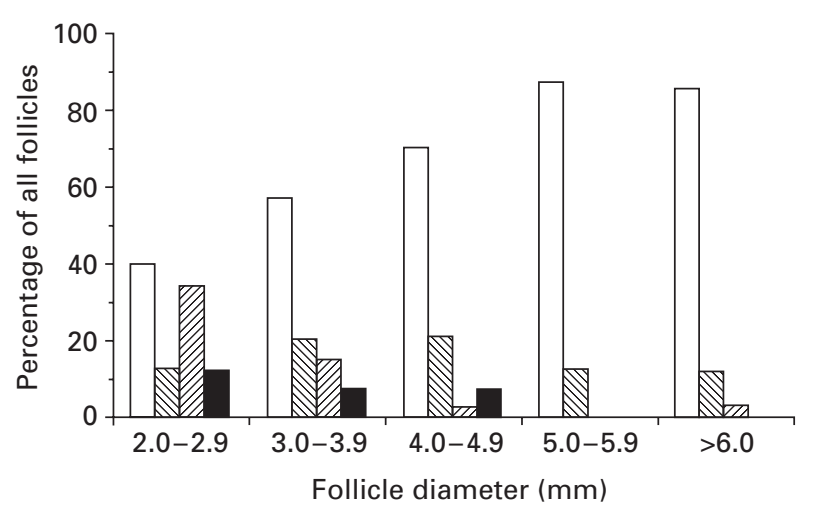

Fig. 1. Percentages of antral follicles ( $\geqslant 2 \mathrm{~mm}$ in diameter) from red deer hinds that were classified as healthy $(\square$ : Grade 1) or as

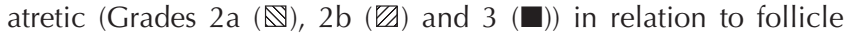
diameter.

were harvested in this study (a total of 666 follicles recovered from 25 hinds) were assessed on the basis of the parameters described above. The two follicles excluded from these analyses included one (estimated diameter $8 \mathrm{~mm}$ ) that had been accidentally burst at the time of recovery of the reproductive tract, thus preventing accurate assessment of its size, number of granulosa cells and follicular fluid hormone concentrations, and one very large $(15.5 \mathrm{~mm}$ diameter) cystic follicle. All 664 remaining follicles were assessed for size, number of granulosa cells and health status on the basis of morphological criteria and follicular fluid oestradiol content. Sufficient granulosa cells were recovered from $75 \%$ (501) of these follicles for determination of aromatase activity in vitro and from 39\% (260) of the follicles for both aromatase activity and cAMP production.

The definition used to characterize a preovulatory $\mathrm{LH}$ surge was that there was a sustained $(>6 \mathrm{~h})$ increase in plasma $\mathrm{LH}$ concentrations $>2 \mathrm{ng} \mathrm{ml}^{-1}$ and that peak concentrations attained during this time were $>5 \mathrm{ng} \mathrm{ml}^{-1}$.

Comparisons of data from ovaries collected at various times over the follicular phase (groups 1-4) or in the luteal phase (group 5) were made by ANOVA performed in conjunction with the Neuman-Keul's test. Comparisons among groups of the number of healthy or atretic follicles, follicular fluid oestradiol content and granulosa cell hormone production rates were made by Student's $t$ test. Unless otherwise stated, all values are presented as mean \pm SEM.

\section{Results}

\section{Classification of deer follicles}

Antral follicle populations and health status. In total, the ovaries of each hind contained a mean $26.6 \pm 3.5$ follicles $\geqslant 2 \mathrm{~mm}$ in diameter (range $4-81$ follicles per hind). On average, $60.4 \%$ of these follicles were between $2.0 \mathrm{~mm}$ and $2.9 \mathrm{~mm}, 25.7 \%$ were between $3.0 \mathrm{~mm}$ and $3.9 \mathrm{~mm}, 6.5 \%$ were between $4.0 \mathrm{~mm}$ and $4.9 \mathrm{~mm}, 2.4 \%$ were between
$5.0 \mathrm{~mm}$ and $5.9 \mathrm{~mm}$, and $5.1 \%$ were $>6 \mathrm{~mm}$ in diameter (see Table 1). Every hind had at least one large $(\geqslant 7.5 \mathrm{~mm}$ in diameter) antral follicle. The mean diameter of the largest follicle was $8.3 \pm 0.4 \mathrm{~mm}$ (range 7.5-10.4 mm).

Approximately half of the follicles were classified as healthy $(50.7 \%$, Grade 1$)$. Of the 329 atretic follicles, $30.8 \%$ were classed as Grade $2 \mathrm{a}, 50.3 \%$ as Grade $2 \mathrm{~b}$ and $18.9 \%$ as Grade 3. The percentage of follicles that were classified as atretic decreased progressively with increasing follicle size, from $59 \%$ of follicles $2.0-2.9 \mathrm{~mm}$ in diameter to $9.1 \%$ of follicles $\geqslant 6.0 \mathrm{~mm}$ in diameter. The distribution of follicle health status in relation to follicle size is shown (Fig. 1).

Number of granulosa cells. When all follicles were included in the analysis, there was a strong correlation between follicle diameter and the number of granulosa cells contained by that follicle $\left(r^{2}=0.676, n=664\right.$; Fig. 2$)$. For each $1 \mathrm{~mm}$ increase in follicle diameter, the number of granulosa cells increased by a mean $0.83 \pm 0.02 \times 10^{6}$ cells. However, this relationship was primarily due to healthy follicles $\left(r^{2}=0.791, n=336\right)$ and not to atretic follicles $\left(r^{2}=0.166, n=328\right)$. The relationship between follicle diameter, follicle health and number of granulosa cells is shown (Fig. 3). In all except two of the size categories, the geometric mean number of granulosa cells present was significantly lower $(P<0.05)$ in atretic than in non-atretic follicles.

Follicular fluid oestradiol content. Oestradiol was measurable (concentrations ranging from 2.3 to $210 \mathrm{ng}$ $\mathrm{ml}^{-1}$ ) in follicular fluid from 83 of 664 follicles. This included fluid from follicles in all size categories and from 16 follicles that had been classified as atretic. All animals had at least one follicle (mean $3.4 \pm 0.47$ follicles containing oestrogen per hind, range 1-9) with measurable concentrations of oestradiol in follicular fluid. The percentage of follicles with measurable oestradiol concentrations increased with follicle size $(4,11,28,63$ and $79 \%$ for follicle diameters of 2.0-2.9, 3.0-3.9, 4.0-4.9, 5.0-5.9 and $\geqslant 6.0 \mathrm{~mm}$, respectively). However, there was a poor correlation between follicle diameter of non-atretic follicles and follicular fluid oestradiol concentration $\left(r^{2}=0.265\right.$, not significant).

A total of 41 follicles had follicular fluid oestradiol concentrations of $>50 \mathrm{ng} \mathrm{ml}^{-1}$, which was one of the criteria used to classify follicles as oestrogenic. Eight of these follicles were atretic follicles and all except two of these atretic follicles had granulosa cell populations lower than the 25 percentile for a follicle of that size category.

Aromatase activity. Granulosa cells from 73 of 501 follicles that had sufficient cells for incubation studies produced measurable amounts of oestradiol (0.18-21.4 ng $\left.\left(10^{6} \text { cells }\right)^{-1} \mathrm{~h}^{-1}\right)$ when incubated in vitro, which included $46 \%$ of the follicles in which concentrations of oestradiol in their follicular fluid were measurable. Only six follicles with 
Table 1. Numbers of follicles of each size category present over the follicular phase of the oestrous cycle (groups 1-4) and in the luteal phase (group 5) in red deer hinds

\begin{tabular}{|c|c|c|c|c|c|c|}
\hline \multirow[b]{2}{*}{ Group } & \multicolumn{6}{|c|}{ Follicle diameter in mm (range) } \\
\hline & $2.0-2.9$ & $3.0-3.9$ & $4.0-4.9$ & $5.0-5.9$ & $\geqslant 6.0$ & Total \\
\hline $1(t=0 \mathrm{~h})$ & $\begin{array}{c}14.8 \pm 7.21 \\
(2-41)\end{array}$ & $\begin{array}{c}5.4 \pm 2.16 \\
(0-13)\end{array}$ & $\begin{array}{c}0.6 \pm 0.24 \\
(0-1)\end{array}$ & $\begin{array}{c}0.2 \pm 0.20 \\
(0-1)\end{array}$ & $\begin{array}{c}1.8 \pm 0.37 \\
(1-3)\end{array}$ & $\begin{array}{c}22.8 \pm 8.22 \\
(4-49)\end{array}$ \\
\hline $2(t=12 \mathrm{~h})$ & $\begin{array}{c}11.2 \pm 4.54 \\
(1-25)\end{array}$ & $\begin{array}{c}8.0 \pm 2.70 \\
(3-18)\end{array}$ & $\begin{array}{c}2.2 \pm 1.02 \\
(0-6)\end{array}$ & $\begin{array}{c}0.2 \pm 0.20 \\
(0-1)\end{array}$ & $\begin{array}{c}1.4 \pm 0.24 \\
(1-2)\end{array}$ & $\begin{array}{c}23.0 \pm 6.86 \\
(6-39)\end{array}$ \\
\hline $3(t=24 \mathrm{~h})$ & $\begin{array}{c}22.2 \pm 11.0 \\
(4-64)\end{array}$ & $\begin{array}{c}6.4 \pm 2.20 \\
(2-14)\end{array}$ & $\begin{array}{c}2.2 \pm 0.73 \\
(1-4)\end{array}$ & $\begin{array}{c}0.8 \pm 0.58 \\
(0-3)\end{array}$ & $\begin{array}{c}1.4 \pm 0.20 \\
(1-2)\end{array}$ & $\begin{array}{c}33.0 \pm 12.9 \\
(11-81)\end{array}$ \\
\hline $4(t=36 \mathrm{~h})$ & $\begin{array}{c}12.4 \pm 3.67 \\
(2-24)\end{array}$ & $\begin{array}{c}6.8 \pm 1.91 \\
(3-14)\end{array}$ & $\begin{array}{c}1.8 \pm 0.86 \\
(0-5)\end{array}$ & $\begin{array}{c}1.4 \pm 0.68 \\
(0-4)\end{array}$ & $\begin{array}{c}1.2 \pm 0.20 \\
(1-2)\end{array}$ & $\begin{array}{c}23.6 \pm 5.17 \\
(9-39)\end{array}$ \\
\hline 5 (luteal) & $\begin{array}{c}19.8 \pm 3.50 \\
(12-30)\end{array}$ & $\begin{array}{c}7.6 \pm 3.08 \\
(1-16)\end{array}$ & $\begin{array}{c}1.8 \pm 0.97 \\
(1-5)\end{array}$ & $\begin{array}{c}0.6 \pm 0.40 \\
(0-2)\end{array}$ & $\begin{array}{l}1.0 \\
(1)\end{array}$ & $\begin{array}{c}30.8 \pm 5.07 \\
(20-48)\end{array}$ \\
\hline All hinds $(n=25)$ & $\begin{array}{c}16.1 \pm 2.84 \\
(1-64)\end{array}$ & $\begin{array}{c}6.8 \pm 1.02 \\
(0-18)\end{array}$ & $\begin{array}{c}1.7 \pm 0.35 \\
(0-6)\end{array}$ & $\begin{array}{c}0.6 \pm 0.21 \\
(0-4)\end{array}$ & $\begin{array}{c}1.4 \pm 0.11 \\
(1-2)\end{array}$ & $\begin{array}{c}26.6 \pm 3.45 \\
(4-81)\end{array}$ \\
\hline
\end{tabular}

Values are mean $\pm \operatorname{SEM}(n=5)$.

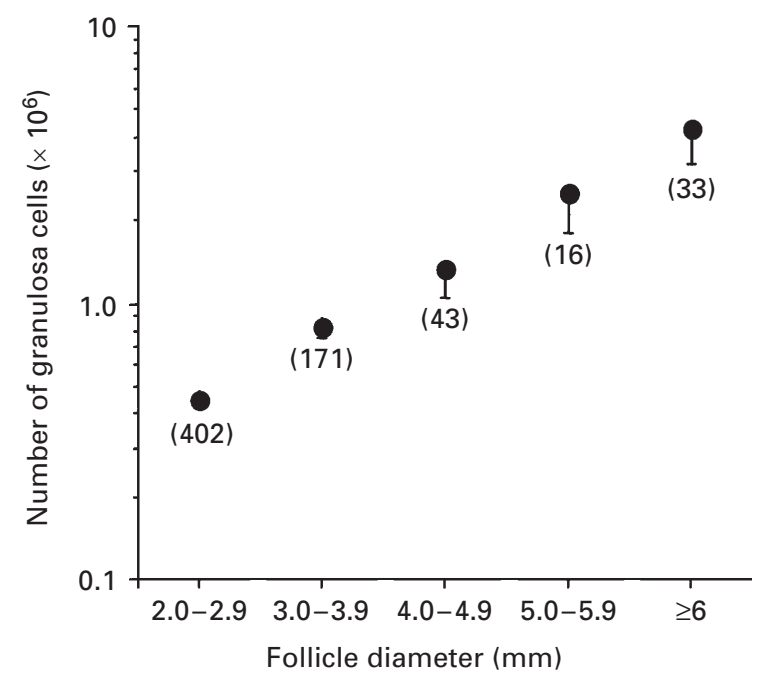

Fig. 2. Mean (geometric mean and 95\% confidence interval) number of granulosa cells recovered from antral follicles in red deer hinds in relation to follicle diameter. Numbers in parentheses show the number of follicles in each size category.

aromatase activity had been classified as atretic. The mean rate of oestradiol production by granulosa cells from these atretic follicles was significantly lower $(P<0.001)$ than that of healthy follicles $(2.4 \pm 1.06$ compared with $\left.6.0 \pm 0.60 \mathrm{ng}\left(10^{6} \text { cells }\right)^{-1} \mathrm{~h}^{-1}\right)$. The percentage of larger follicles capable of producing oestradiol in vitro was not significantly different among follicle size categories (43, 60 and $56 \%$ for follicles $4.0-4.9,5.0-5.9$ and $\geqslant 6.0 \mathrm{~mm}$ in diameter, respectively), but decreased abruptly for smaller follicles (9 and 4\% for follicles 3.0-3.9 and 2.0-2.9 $\mathrm{mm}$ in diameter, respectively). There was a poor correlation between follicle size and oestradiol secretion rate ( $r^{2}=0.428$, not significant).

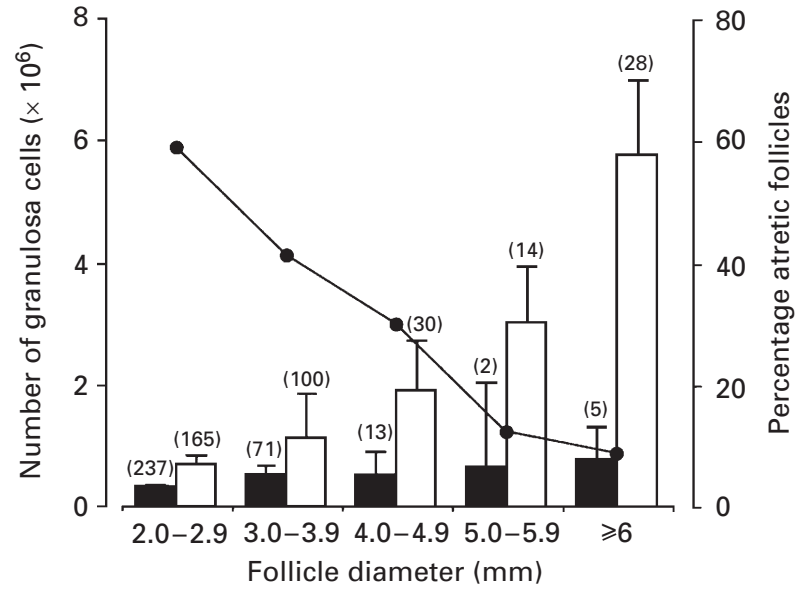

Fig. 3. Mean (geometric mean and 95\% confidence interval) number of granulosa cells recovered from non-atretic $(\square)$ or atretic (ם) antral follicles in red deer hinds $(n=25)$ in relation to follicle diameter. Also shown $(\mathbf{0})$ is the percentage of follicles of each size category that were atretic. Numbers in parentheses show the number of follicles in each category.

cAMP production. Granulosa cells from 105 of 260 follicles assessed produced measurable quantities of CAMP $\left(0.16-77.0 \mathrm{pmol}\left(10^{6} \text { cells }\right)^{-1} \mathrm{~h}^{-1}\right)$. Only six follicles classified as atretic produced measurable quantities of cAMP and four of these produced $<0.3 \mathrm{pmol}\left(10^{6} \mathrm{cells}\right)^{-1} \mathrm{~h}^{-1}$.

Granulosa cells from a high percentage of the larger follicles assessed were capable of producing cAMP $(85,73$ and $75 \%$ of follicles $4.0-4.9,5.0-5.9$ and $\geqslant 6.0 \mathrm{~mm}$ in diameter, respectively), but few small follicles responded (37 and $7 \%$ of follicles 3.0-3.9 and 2.0-2.9 in $\mathrm{mm}$ diameter, respectively). There was poor correlation between follicle size and the rate of cAMP production $\left(r^{2}=0.223\right.$, not significant $)$. 


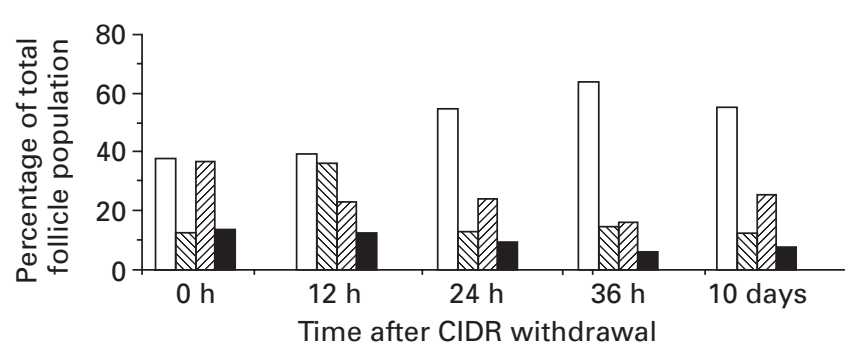

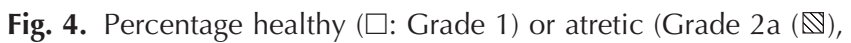
Grade $2 \mathrm{~b}(\mathbb{Q})$ and Grade $3(\boldsymbol{\square}))$ antral follicles in red deer hinds ( $n=5$ per group) during the follicular phase $(0,12,24$ and $36 \mathrm{~h}$ ) and in the luteal phase (10 days) of the oestrous cycle. Times shown are in relation to time after withdrawal of progesterone (CIDR implant).

Oestrogenic follicles. A total of 33 of the follicles recovered (range 1-4 follicles per hind) was classified as oestrogenic. These follicles had a mean diameter of $6.7 \pm 0.38 \mathrm{~mm}$, a mean granulosa cell population of $5.5 \pm 0.57 \times 10^{6}$ and a follicular fluid concentration of $143 \pm 18.3 \mathrm{ng} \mathrm{ml}^{-1}$. When incubated in vitro, their granulosa cells produced oestradiol at a mean rate of $4.2 \pm 0.52 \mathrm{ng}\left(10^{6} \text { cells }\right)^{-1} \mathrm{~h}^{-1}$ and cAMP at $10.2 \pm$ 2.17 pmol $\left(10^{6} \text { cells }\right)^{-1} \mathrm{~h}^{-1}$.

In contrast, atretic follicles that had follicular fluid concentrations $\geqslant 50 \mathrm{ng} \mathrm{ml}^{-1}(n=8)$ had a mean diameter of $3.7 \pm 0.66 \mathrm{~mm}$, a mean granulosa cell population of $0.4 \pm 0.23 \times 10^{6}$ and follicular fluid concentration of $114 \pm 29.0 \mathrm{ng} \mathrm{ml}^{-1}$.

\section{Follicle development during the follicular phase}

Timing of oestrus and the $\mathrm{LH}$ surge in relation to ovary recovery. Four of the five control hinds were recorded in oestrus (mean time of onset $45.5 \pm 6.8 \mathrm{~h}$ ) and a preovulatory LH surge occurred in all of these animals (mean time of onset $44.5 \pm 6.6 \mathrm{~h}$ after CIDR removal). Neither oestrus nor a preovulatory LH surge was recorded during the $72 \mathrm{~h}$ of monitoring in the other hind. The mean times of ovary collection from the other five groups (nominally set as $0,12,24$ or $36 \mathrm{~h}$ and 10 days after CIDR withdrawal) were actually $0 \pm 0 \mathrm{~h}$ (group 1 , immediately before CIDR withdrawal), $12.6 \pm 0.38 \mathrm{~h}$ (group 2), $27.2 \pm 0.65 \mathrm{~h}$ (group 3 ) and $38.9 \pm 0.36 \mathrm{~h}$ (group 4) and 10 days (group 5) after CIDR withdrawal.

Antral follicle populations. Mean ovarian mass ( $1.37 \pm 0.12 \mathrm{~g}$, range $0.54-3.50 \mathrm{~g}$ for individual ovaries) did not differ significantly among times of ovary collection. Mean numbers of follicles of each size category within each of the treatment groups are shown (Table 1). Neither the total number of follicles present nor their size distribution differed significantly among the different times of ovary collection. In all hinds there was at least one follicle that was $\geqslant 7.5 \mathrm{~mm}$ in diameter, including 22 hinds with one
Table 2. Numbers of healthy, large ( $\geqslant 4.0 \mathrm{~mm}$ in diameter), oestrogenic follicles during the follicular phase of the oestrous cycle (groups 1-4) and in the luteal phase (group 5) in red deer hinds

\begin{tabular}{lccc}
\hline Group & $\begin{array}{c}\text { Number of healthy } \\
\text { follicles (range) }\end{array}$ & $\begin{array}{c}\text { Number of } \\
\text { follicles } \geqslant 4 \mathrm{~mm} \text { in diameter } \\
\text { (range) }\end{array}$ & $\begin{array}{c}\text { Number of } \\
\text { oestrogenic } \\
\text { follicles } \\
\text { (range) }\end{array}$ \\
\hline $1(t=0 \mathrm{~h})$ & $\begin{array}{c}8.0 \pm 1.64 \\
(4-13)\end{array}$ & $\begin{array}{c}2.6 \pm 0.40 \\
(2-4)\end{array}$ & $\begin{array}{c}0.8 \pm 0.37 \\
(0-2)\end{array}$ \\
$2(t=12 \mathrm{~h})$ & $9.0 \pm 2.47$ & $3.8 \pm 0.97$ & $1.2 \pm 0.20$ \\
& $(3-18)$ & $(1-7)$ & $(1-2)$ \\
$3(t=24 \mathrm{~h})$ & $18.0 \pm 4.44$ & $4.4 \pm 0.40$ & $1.8 \pm 0.49$ \\
& $(7-29)$ & $(3-5)$ & $(1-3)$ \\
$4(t=36 \mathrm{~h})$ & $15.0 \pm 4.30$ & $4.4 \pm 1.50$ & $1.0 \pm 0.58$ \\
& $(1-10)$ & $(1-10)$ & $(0-2)$ \\
5 (luteal) & $17.0 \pm 3.95$ & $3.4 \pm 1.36$ & $1.8 \pm 0.80$ \\
& $(8-28)$ & $(1-8)$ & $(1-5)$ \\
\hline
\end{tabular}

Values are mean $\pm \operatorname{SEM}(n=5)$.

follicle and three hinds (one from each of groups 1, 2 and 3) with two follicles of that diameter.

Follicle health status. The percentage of healthy and atretic follicles over the follicular phase is shown (Fig. 4) and the mean numbers of (i) healthy, (ii) large ( $\geqslant 4 \mathrm{~mm}$ in diameter) and (iii) oestrogenic follicles are shown (Table 2). The mean numbers of both healthy and large follicles were significantly higher at $24 \mathrm{~h}$ after (group 3), than at the time of progesterone withdrawal (group 1). These parameters were not significantly different among other groups. The number of oestrogenic follicles present did not differ significantly among the times of ovary collection, but there was a trend for fewer oestrogenic follicles at the time of progesterone removal compared with $24 \mathrm{~h}$ later (group 3) and in the luteal phase (group 5), although this was not significant.

Preovulatory follicle development. The mean diameters of the single largest follicle present, of the largest healthy or oestrogenic follicle, and of the dominant follicle in each group are shown (Table 3 ). With the single exception that the mean diameters of the largest oestrogenic and that of the dominant follicle were both significantly smaller $(P<0.05)$ late in the follicular phase (group 4, $36 \mathrm{~h}$ after progesterone withdrawal), there were no differences in large antral follicle populations among groups.

The endocrine capacity of the largest oestrogenic follicle present at each of the ovary collection times is shown (Table 4). The mean granulosa cell complement of these follicles did not differ with stage of the follicular phase but was significantly lower $(P<0.01)$ in progesterone-implanted hinds (group 1) than in the luteal phase of the oestrous cycle (group 5). Follicular fluid oestradiol concentrations and aromatase activity were both significantly lower in 
Table 3. Diameters of the single largest, largest healthy, largest oestrogenic and dominant follicles during the follicular phase of the oestrous cycle (groups 1-4) and in the luteal phase (group 5) in red deer hinds

\begin{tabular}{|c|c|c|c|c|}
\hline Group & Largest & Largest healthy & Largest oestrogenic & Dominant \\
\hline $1(t=0 \mathrm{~h})$ & $\begin{array}{c}8.4 \pm 0.51 \\
(5 / 5)\end{array}$ & $\begin{array}{c}8.3 \pm 0.56 \\
(5 / 5)\end{array}$ & $\begin{array}{c}7.7 \pm 0.29 \\
(3 / 5)\end{array}$ & $\begin{array}{c}7.4 \pm 0.35 \\
(3 / 5)\end{array}$ \\
\hline $2(t=12 \mathrm{~h})$ & $\begin{array}{c}8.9 \pm 0.42 \\
(5 / 5)\end{array}$ & $\begin{array}{c}8.9 \pm 0.42 \\
(5 / 5)\end{array}$ & $\begin{array}{c}8.9 \pm 0.42 \\
(5 / 5)\end{array}$ & $\begin{array}{c}8.9 \pm 0.42 \\
(5 / 5)\end{array}$ \\
\hline $3(t=24 \mathrm{~h})$ & $\begin{array}{c}8.9 \pm 0.33 \\
(5 / 5)\end{array}$ & $\begin{array}{c}8.2 \pm 0.74 \\
(5 / 5)\end{array}$ & $\begin{array}{c}8.2 \pm 0.74 \\
(5 / 5)\end{array}$ & $\begin{array}{c}8.2 \pm 0.74 \\
(5 / 5)\end{array}$ \\
\hline $4(t=36 \mathrm{~h})$ & $\begin{array}{c}8.4 \pm 0.40 \\
(5 / 5)\end{array}$ & $\begin{array}{c}8.4 \pm 0.40 \\
(5 / 5)\end{array}$ & $\begin{array}{c}6.3 \pm 0.88 \\
(4 / 5)\end{array}$ & $\begin{array}{c}6.3 \pm 0.68 \\
(3 / 5)\end{array}$ \\
\hline 5 (luteal) & $\begin{array}{c}8.2 \pm 0.20 \\
(5 / 5)\end{array}$ & $\begin{array}{c}8.2 \pm 0.20 \\
(5 / 5)\end{array}$ & $\begin{array}{c}8.2 \pm 0.20 \\
(5 / 5)\end{array}$ & $\begin{array}{c}8.2 \pm 0.20 \\
(5 / 5)\end{array}$ \\
\hline
\end{tabular}

Values are mean \pm SEM.

Values in parentheses show the number of hinds in which follicles of each class were present.

Table 4. Number of granulosa cells, follicular fluid oestradiol concentration, aromatase activity and cAMP production in the largest oestrogenic follicle during the follicular phase of the oestrous cycle (groups 1-4) and in the luteal phase (group 5) in red deer hinds

\begin{tabular}{|c|c|c|c|c|}
\hline Group & $\begin{array}{c}\text { Number of } \\
\text { granulosa cells } \\
\left(\times 10^{6}\right)\end{array}$ & $\begin{array}{l}\text { Follicular } \\
\text { fluid oestradiol } \\
\text { concentration } \\
\left(\mathrm{ng} \mathrm{ml}^{-1}\right)\end{array}$ & $\begin{array}{l}\text { Aromatase activity } \\
\text { (ng oestradiol } \\
\left.\left(10^{6} \text { cells }\right)^{-1} \mathrm{~h}^{-1}\right)\end{array}$ & $\begin{array}{l}\text { cAMP production } \\
\left(\text { pmol }\left(10^{6} \text { cells }\right)^{-1} \mathrm{~h}^{-1}\right)\end{array}$ \\
\hline $1(t=0 \mathrm{~h})$ & $5.7 \pm 0.52$ & $76 \pm 19.3$ & $0.7 \pm 0.16$ & $6.8 \pm 5.01$ \\
\hline $2(t=12 \mathrm{~h})$ & $8.5 \pm 1.68$ & $177 \pm 39.4$ & $4.1 \pm 0.48$ & $7.9 \pm 2.74$ \\
\hline $3(t=24 h)$ & $6.7 \pm 1.56$ & $299 \pm 73.7$ & $6.7 \pm 1.16$ & $24.6 \pm 8.46$ \\
\hline $4(t=36 \mathrm{~h})$ & $5.7 \pm 1.29$ & $106 \pm 25.8$ & $4.2 \pm 2.86$ & $9.3 \pm 6.76$ \\
\hline 5 (luteal) & $8.3 \pm 0.26$ & $129 \pm 23.8$ & $4.7 \pm 1.36$ & $11.0 \pm 5.33$ \\
\hline
\end{tabular}

Values are mean $\pm \operatorname{SEM}(n=5)$.

progesterone-implanted hinds $(P<0.05)$ than in other groups, but cAMP production did not differ significantly.

\section{Discussion}

In the present study, the antral follicle populations recorded over the follicular phase of the oestrous cycle and characteristics of antral follicles observed in red deer hinds were not dissimilar to those reported for other monovular ruminant species. The total number of antral follicles present, and their size distribution, was comparable to those reported for sheep (McNatty et al., 1982, 1984b; Driancourt et al., 1990) and cattle (McNatty et al., 1984a). The number of granulosa cells per follicle was similar to that reported for non-atretic follicles of comparable sizes in sheep in studies that used the same method for quantifying cell numbers (McNatty et al., 1985; McNatty and Henderson, 1987). In addition, O'Shea et al. (1987) reported similar numbers of granulosa cells in sheep preovulatory follicles (mean follicle diameter: $6.25 \pm 0.25 \mathrm{~mm}$; granulosa cells: $7.68 \pm 0.53 \times 10^{6}$ ) using a morphometric method to estimate cell numbers under light microscopy. In the present study, follicular fluid oestradiol concentrations, aromatase activity and cAMP production varied widely among follicles of the same diameter. However all these parameters were within the ranges reported previously in sheep and cattle (McNatty et al., 1982, 1984a,b).

Although the criteria used to classify health status of deer follicles in the present study were based largely on those used in other species, it would appear that they were appropriate for this species. Only one follicle $(3.6 \mathrm{~mm}$ in diameter) that was classified as atretic had high concentrations of oestradiol (>50 ng ml-1) in its follicular fluid, had aromatase activity (4.0 ng per $10^{6}$ cells) and produced measurable cAMP (4.5 pmol per $10^{6}$ cells $)$ in vitro. This follicle had a granulosa cell population greater than the ninetieth percentile for follicles of that size, indicating that it may have been classified incorrectly. It had been defined as atretic solely on the basis of debris in follicular fluid, which could have been an artefact that occurred during processing (for example, damage to vasculature during dissection).

The time over which ovaries were recovered (at approximately $12 \mathrm{~h}$ intervals from $0 \mathrm{~h}$ to $39 \mathrm{~h}$ after progesterone withdrawal) appears to have been appropriate for investigating preovulatory development over the 
follicular phase of the oestrous cycle in red deer. The preovulatory $\mathrm{LH}$ surge was recorded at a mean time of $45 \mathrm{~h}$ after progesterone withdrawal in control herd mates, a time that was identical to that reported in an earlier study in red deer hinds (Asher et al., 1992). The consistent trend for a decrease in mean numbers of oestrogenic follicles, follicular fluid oestradiol concentrations, aromatase activity and cAMP production in group 4 hinds (ovaries recovered approximately $39 \mathrm{~h}$ after progesterone withdrawal) compared with those in group 3 (ovaries recovered approximately $27 \mathrm{~h}$ after progesterone withdrawal) indicates that the preovulatory LH surge had already occurred in some of these animals. Steroid hormone production is altered markedly by the LH surge, which is associated with a decrease in aromatizable androgen and oestrogen concentrations in follicular fluid (Murdoch and Dunn, 1982).

There were no significant changes in the numbers of follicles present or in the percentages of healthy or oestrogenic follicles over the follicular phase. This finding is in agreement with other reports for cattle and sheep (McNatty et al., 1984a,b). However, Grant et al. (1989) reported that in a multi-ovulatory species (pigs) the mean total number of follicles recovered decreased (from 36 follicles to 11 follicles $\geqslant 2 \mathrm{~mm}$ in diameter per animal) as the follicular phase progressed.

To our knowledge, the only other study of antral follicle populations in red deer was a study that involved hinds taken from the same herd as that used in the present study (Asher et al., 1997). In that investigation, follicle development was monitored daily by transvaginal real-time ultrasonography over a complete ovulatory cycle in hinds that had been modified surgically (the ovarian ligament was severed and ovaries were attached to the vaginal wall). There were similarities in the follicle populations described by both methods. However, the number of antral follicles $\geqslant 3 \mathrm{~mm}$ in diameter in the present study $(10.4 \pm 1.18$ follicles per hind) was significantly greater than that reported by ultrasonography (1.8-3.4 follicles per hind; Asher et al., 1997). This difference may have been due to imprecision in estimating follicle diameter by ultrasonography, which may have resulted in underestimation of follicle size. In the present study, when follicle populations were determined by dissection of the ovaries the mean number of follicles $\geqslant 4 \mathrm{~mm}$ in diameter $(3.8 \pm 0.44$ follicles per hind) closely paralleled the ultrasonography estimate for numbers of follicles $\geqslant 3 \mathrm{~mm}$ in diameter. It is also possible that differences in follicle populations were due to artefacts of the surgical modifications imposed in the ultrasonography study, as there was a high incidence of cystic follicles in these hinds.

It is interesting to note that there were significant differences in follicle populations and in the steroidogenic competence of follicles between group 1 (time zero) and group 5 (luteal phase) hinds. Both of these groups would have been exposed to increased plasma progesterone concentrations at the time of ovary recovery, the former from an exogenous source (CIDRs) and the latter from endogenous secretion by the corpus luteum. In the hinds exposed to exogenous progesterone (group 1), there were significantly fewer healthy follicles and a trend for fewer large and oestrogenic follicles. Furthermore, although the largest oestrogenic follicle present was of comparable diameter to that recovered in the luteal phase, it had fewer granulosa cells, lower follicular fluid oestradiol concentrations and lower aromatase activity. This finding indicates that exposure to exogenous progesterone for an extended period adversely affects the competency of antral follicles. As the progesterone-releasing device was replaced after 8 days ( 4 days before recovery of the ovaries), it would be expected that these animals would have been subjected to high plasma concentrations of progesterone. Nevertheless, it is unlikely that the disruption to follicle health was simply due to progesterone concentrations per se, but more likely to an extended lifespan of antral follicles. Exposure to exogenous progestagens extends the longevity of presumptive preovulatory follicles (Kinder et al., 1996) and artificial prolongation of ovulatory follicles is associated with reduced fertility (Mihm et al., 1996). In the present study, exposure to a prolonged period of increased progesterone concentration adversely affected large antral follicles. Kinder et al. (1996) showed that LH pulse frequency (and consequently, longevity of antral follicles) during periods of exogenous progestagen treatment was inversely related to the plasma progestagen concentrations imposed.

One feature of follicle development in deer observed in the present study was that there was invariably at least one large follicle (approximately $8 \mathrm{~mm}$ in diameter) present, irrespective of the stage of the oestrous cycle. This finding has also been observed during seasonal anoestrus, in prepubertal hinds and in induced superovulation (B. J. McLeod, L. M. Meikle, M. W. Fisher, G. H. Shackell and D. A. Heath, unpublished). In contrast to our findings, Asher et al. (1997) reported that few hinds had follicles $\geqslant 6 \mathrm{~mm}$ in diameter over the first 3-4 days after ovulation. It is possible that the absence of large follicles at that time was due to the presence of cystic follicles in the surgically modified animals. Alternatively, the presence of large follicles early in the follicular phase in the present study may have been the result of the progesterone treatment that hinds were exposed to immediately before ovary collection.

In conclusion, these data indicate that the reported interanimal variation in response to controlled breeding strategies in deer is unlikely to be due to differences in antral follicle populations or in their health status. The results of the present study indicate that administration of exogenous progesterone in the treatment regimens used may adversely affect follicle health and, as a consequence, subsequent follicle development. There were no specific characteristics of follicle development that would indicate that the low incidence of twinning, or the synchrony of onset of breeding in this species, is primarily under ovarian control.

The authors would like to thank G. Shackell and C. Mackintosh for assistance with surgery, the staff of the Invermay Deer Unit for 
assistance with all aspects of deer handling and sample collection and the Pituitary Hormone Distribution Program, NIADDK, NIH, Baltimore, MD, USA, for the pituitary hormone and RIA kits.

\section{References}

Asher GW, Fisher MW, Jabbour HN, Smith JF, Mulley RC, Morrow CJ, Veldhuizen FA and Langridge M (1992) Relationship between the onset of oestrus, the preovulatory surge in luteinizing hormone and ovulation following oestrous synchronization and superovulation of farmed red deer (Cervus elaphus) Journal of Reproduction and Fertility 96 261-273

Asher GW, Jabbour HN, Thompson JGE, Tervit HR and Morrow CJ (1994) Superovulation of farmed red deer (Cervus elaphus) and fallow deer (Dama dama): incidence of ovulation and changes in plasma hormone concentrations during the pre-ovulatory period in relation to ova recovery and fertilisation Animal Reproduction Science 38 135-154

Asher GW, Scott IC, O'Neill KT, Smith JF, Inskeep EK and Townsend EC (1997) Ultrasonographic monitoring of antral follicle development in red deer (Cervus elaphus) Journal of Reproduction and Fertility 111 91-99

Driancourt MA, Castonguay F, Bindon BM, Piper LR, Quirke JF and Hanrahan JP (1990) Ovarian follicular dynamics in lines of sheep (Finn, Merino) selected on ovulation rate Journal of Animal Science $\mathbf{6 8}$ 2034-2041

Fennessey PF, Asher GW, Beatson NS, Dixon TE, Hunter JW and Bringans MJ (1994) Embryo transfer in deer Theriogenology 41 133-138

Fisher MW, Fennessey PF, Henderson KM, Newman RE and Manley TR (1989) Induction of twin ovulations in red deer hinds with steroid-free bovine follicular fluid Proceedings of the New Zealand Society of Animal Production 49 103-106

Fortune JE (1994) Ovarian follicular growth and development in mammals Biology of Reproduction 50 225-232

Grant SA, Hunter MG and Foxcroft GR (1989) Morphological and biochemical characteristics during ovarian follicle development in the pig Journal of Reproduction and Fertility 86 171-183

Hay MF, Cran DG and Moor RM (1976) Structural changes occurring during atresia in sheep ovarian follicles Cell Tissue Research 169 515-529

Henderson KM, Kieboom LE, McNatty KP, Lun S and Heath DA (1985) Gonadotrophin stimulated cyclic AMP production by granulosa cells from Booroola $\times$ Romney ewes with and without the fecundity gene Journal of Reproduction and Fertility 75 111-120

Hunter MG, Biggs C, Faillace LS and Picton HM (1992) Current concepts of folliculogenesis in monovular and polyovular farm species Journal of Reproduction and Fertility Supplement 45 21-38

Kinder JE, Kojima FN, Bergfeld EGM, Wehrman ME and Fike KE (1996) Progestin and estrogen regulation of pulsatile $\mathrm{LH}$ release and development of persistent ovarian follicles in cattle Journal of Animal Science $\mathbf{7 4}$ 1424-1440

Lincoln GA and Guinness FE (1973) The sexual significance of the rut in deer Journal of Reproduction and Fertility Supplement 19 475-489

McLeod BJ, Meikle LM, Heath DA, McNatty KP and Fisher MW (1994) Ovarian follicle development in the red deer hind. In Recent Developments in Deer Biology pp 181 Ed. JA Milne. McCauley Land Use Research Institute, Aberdeen and Moredun Research Institute, Edinburgh
McLeod BJ, Meikle LM, Heath DA, McNatty KP, Fisher MW and Whaanga AJ (1996) Ovarian follicle development in the red deer hind Proceedings of the New Zealand Society of Animal Production 56 370-372

McNatty KP (1982) Ovarian follicle development from the onset of luteal regression in humans and sheep. In Follicular Maturation and Ovulation pp 1-18 Eds R Rolland, EV van Hall, SG Hillier, KP McNatty and J Shoemaker. Excerpta Medica Press, Amsterdam

McNatty KP and Henderson KM (1987) Gonadotrophins, fecundity genes and ovarian follicular function Journal of Steroid Biochemistry 27 365-373

McNatty KP, Gibb M, Dobson C, Thurley DC and Findlay JK (1981) Changes in the concentrations of gonadotrophic and steroidal hormones in the antral fluid of ovarian follicles throughout the oestrous cycle of the sheep Australian Journal of Biological Sciences 34 67-80

McNatty KP, Gibb M, Dobson C, Ball K, Coster J, Heath D and Thurley DC (1982) Preovulatory follicle development in sheep treated with PMSG and/or prostaglandin Journal of Reproduction and Fertility 55 111-123

McNatty KP, Heath DA, Henderson KM, Lun S, Hurst PR, Ellis LM, Montgomery GW, Morrison L and Thurley DC (1984a) Some aspects of thecal and granulosa cell function during follicular development in the bovine ovary Journal of Reproduction and Fertility 72 39-53

McNatty KP, Hudson NL, Henderson KM, Lun S, Heath DA, Gibb M, Ball K, McDiarmid JM and Thurley DC (1984b) Changes in gonadotrophin secretion and ovarian antral follicular activity in seasonally breeding sheep throughout the year Journal of Reproduction and Fertility $\mathbf{7 0}$ 309-321

McNatty KP, Henderson KM, Lun S et al. (1985) Ovarian activity in Booroola $\times$ Romney ewes have a major gene influencing ovulation rate Journal of Reproduction and Fertility 73 109-120

McNatty KP, Heath DA, Hudson NL and Clarke IJ (1990) Effect of long-term hypophysectomy on ovarian follicle populations and gonadotrophininduced adenosine cyclic 3', 5'-monophosphate output by follicles from Booroola ewes with or without the F gene Journal of Reproduction and Fertility 90 515-521

Meikle LM and Fisher MW (1996) Regulation of seasonality in the red deer hind: oestradiol-dependent and -independent influences on the patterns of LH concentrations Journal of Reproduction and Fertility 106 213-220

Mihm M, Baguisi A, Boland MP and Roche JF (1996) Association between the duration of dominance of the ovulatory follicle and pregnancy rate in beef heifers Journal of Reproduction and Fertility 102 123-130

Murdoch WJ and Dunn TG (1982) Alterations in follicular steroid hormones during the preovulatory period in the ewe Biology of Reproduction 24 1171-1181

O'Shea JD, Wright PJ and Davis KE (1987) Morphometric estimation of the numbers of granulosa cells in preovulatory follicles of the ewe Australian Journal of Biological Science 40 451-457

Webb R, Gould IK and Driancourt MA (1989) Morphological and functional characteristics of large antral follicles in three breeds of sheep with different ovulation rates Journal of Reproduction and Fertility $\mathbf{8 7}$ 243-255

Received 11 September 2000.

First decision 30 October 2000

Accepted 12 December 2000. 